\title{
CHEMICAL AND BIOLOGICAL INVESTIGATIONS OF THE ROOTS OF SONCHUS OLERACEUS L. GROWING IN EGYPT
}

\author{
Ehab Saad Elkhayat
}

Department of Pharmacognosy, Faculty of Pharmacy, Al-Azhar University, Assiut branch, Assiut 71524, Egypt

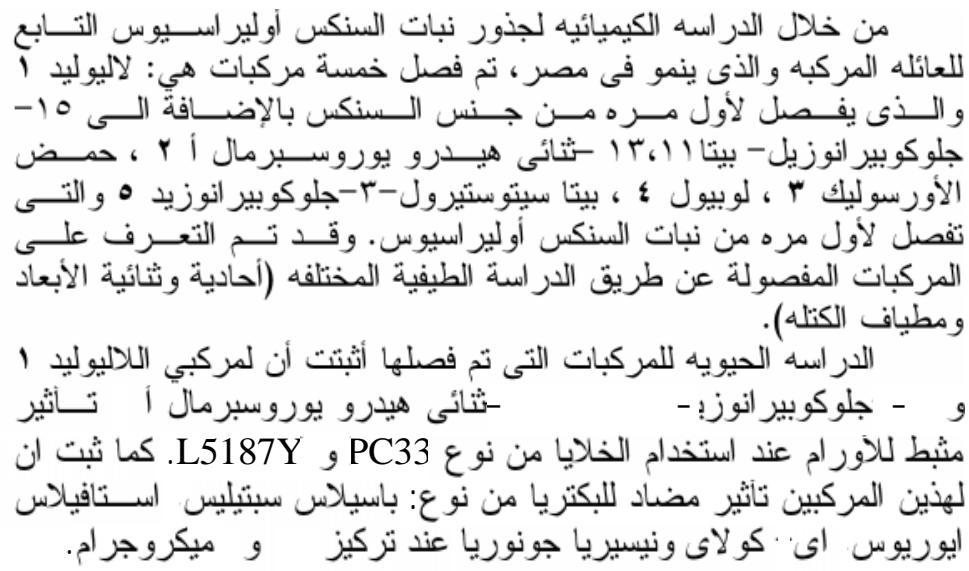

Phytochemical study of the roots of Sonchus oleraceus $L$. (Astraceae) growing in Egypt, afforded loliolide 1 for the first time from the genus Sonchus in addition to 15-O- $\beta$-glucopyranosyl11 $\beta, 13$-dihydrourospermal A 2, ursolic acid 3, lupeol 4, and $\beta$ sitosterol-3-O- $\beta$-glucopyranoside 5 for the first time from the species. The biological evaluation of the isolated compounds showed cytotoxic activity of 1 and 2 against L5187Y cell line, while compound 2 showed activity against PC33 cell line. In addition to antibacterial activity of compounds 1 and $\mathbf{2}$ against $S$. aureus, B. subtilis, E. Coli, and N. gonorrhoea. The structures of the isolated compounds were elucidated using $1 D\left({ }^{1} \mathrm{H}\right.$ and $\left.{ }^{13} \mathrm{C}\right), 2 \mathrm{D}(\mathrm{H}-\mathrm{H}$ COSY, HMQC and HMBC) NMR and MS spectroscopic data.

\section{INTRODUCTION}

The genus Sonchus belongs to sub-tribe Crepidinea, tribe Lactuceae and family Astraceae ${ }^{1}$ and includes more than 50 species $^{2}$. This genus is represented in Egypt by five species namely: maritimus, oleraceus, asper, 
macrocarpus and tenerrimus ${ }^{3}$. Sonchus plants are well-known with their content of sesqueterpene lactones of the eudismanolide ${ }^{4 \& 5}$ and guaianolide structures ${ }^{6}$. Other constituents include ionone glycosides ${ }^{7}$, phenyl propanoids ${ }^{8}$, phenolics [flavonoids and coumarins] ${ }^{9}$, in addition to sterols and lignans ${ }^{10}$.

Sonchus oleraceus L. which is a common annual herb, with erect stem branched near the pale yellow inflorescence $^{11}$ and known as smooth sow-thistle ${ }^{12}$. In Upper Egypt it is commonly known as lobbain due to its milky juice secretion. Previous studies of S. oleraceus L. reported the isolation of eudes-manolide and guaianolide lactone glycosides from the aerial parts of the plant growing in Japan $^{13}$ and the detection of flavone glycosides in the plant growing in Canary Island ${ }^{2}$. This paper describes the phytochemical investigation of the
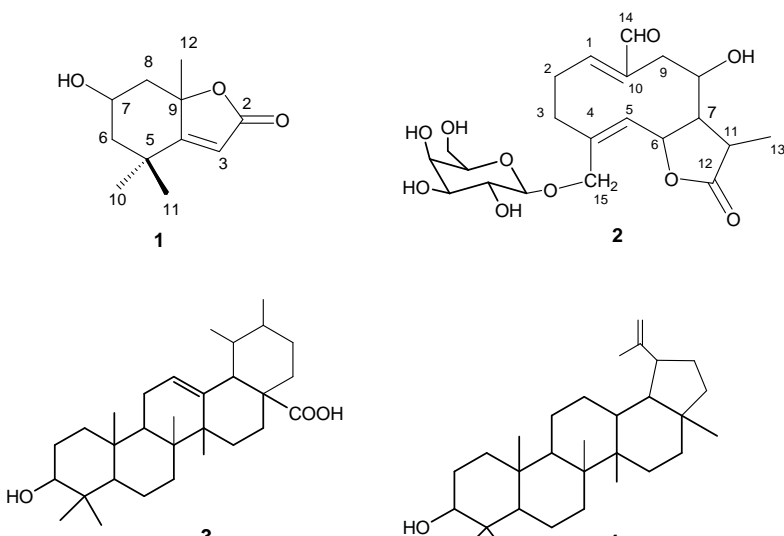<smiles>C=C(C)C1CCC2(C)CCC3(C)C4CCC5C(CCC6(C)C(O)CCC56C)C4CCC3C12</smiles>

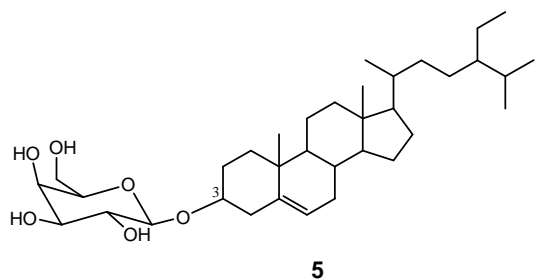

Fig. 1: Structure of compounds 1-5. roots of the plant growing in Egypt as well as the biological evaluation of the isolated compounds. Where the monoterpene loliolide $\mathbf{1}$ was isolated for the first time from the genus Sonchus, in addition to 15-O- $\beta$ glucopyranosyl-11 $\beta$, 13-dihydrourospermal A 2, ursolic acid 3, lupeol 4 and $\beta$-sitosterol-3-O-glucopyranoside 5 (Fig. 1), which were isolated for the first time from the species. Besides, the crude alcoholic extract, compound $\mathbf{1}$ and $\mathbf{2}$ showed antibacterial and antifungal activities against Bacillus subtilis, Staphylococcus aureus, Escherichia coli and Neisseria gonorrhoea, and the fungal strains: Candida albicans and Aspergillus flavus. Compounds $\mathbf{1}$ and 2 showed in-vitro cytotoxic activity against L5187Y cell line while $\mathbf{2}$ only showed cytotoxic activity against PC33 cell line. 


\section{EXPERIMENTAL}

\section{General experimental procedures}

Pre-coated silica gel $60 \mathrm{~F}_{254}$ plates

(Merck) were used for TLC. Vacuum liquid chromatography (VLC) was carried out using silica gel 60, 0.04$0.063 \mathrm{~mm}$ mesh size (Merck). The solvent systems used for TLC analysis were n-hexane-EtoAc (9:1, system I), $\mathrm{CHCl}_{3}-\mathrm{MeOH}$ (9:1, system II) and $\mathrm{CHCl}_{3}-\mathrm{MeOH}$ (75:25, system III). The TLC plates were visualized by spraying with $p$-anisaldehyde $/ \mathrm{H}_{2} \mathrm{SO}_{4}$ reagent and heating at $110^{\circ} \mathrm{C}$ for 1-2 min. ${ }^{1} \mathrm{H}$ and ${ }^{13} \mathrm{C}-\mathrm{NMR}$ spectra were recorded on a JEOL-JNM-EX400 spectrometer $\left(400 \mathrm{MHz}\right.$ for ${ }^{1} \mathrm{H}$ and $100 \mathrm{MHz}$ for ${ }^{13} \mathrm{C}$ ). EI-MS data were obtained with a JEOL JMS-700T mass spectrometer. The melting point was determined using an Electrothermal 9100 Digital melting point apparatus (Electrothermal Engineering Ltd, Essex, England). The IR spectrum was carried out using Shimadzu Infrared400 spectrophotometer (Kyoto, Japan). All solvents were distilled prior to use. NMR grade solvents (Merck) were used for NMR analysis.

\section{Plant material}

The fresh roots of $S$. oleraceus L. were collected in March and April 2007 from the wild plants around the campus of Al-Azhar University, Assiut, Egypt. The plant material was kindly identified by Prof. Dr. A. Fayed, Professor of Plant Taxonomy, Faculty of Science, Assiut University, Egypt. A voucher specimen was deposited in the Department of Pharmacognosy herbarium, Faculty of Pharmacy, Al-Azhar University, Assiut (Registration code W. Az-007 So).

\section{Extraction and isolation}

The air-dried powdered roots of $S$. oleraceus $(0.9 \mathrm{~kg})$ were extracted with $70 \% \mathrm{MeOH}(4 \times 3 \mathrm{~L})$ at room temperature; evaporation of the methanol extract under reduced pressure affords a dark brown oily residue $(7.6 \mathrm{~g})$. The residue was subjected to VLC on silica gel using $\mathrm{CHCl}_{3}$ : $\mathrm{MeOH}$ gradient (starting with $100 \% \mathrm{CHCl}_{3}$ to $100 \% \mathrm{MeOH}$ ) and afforded 6 fractions. Fraction I was chromatographed on silica gel column and eluted with $\mathrm{CHCl}_{3}: \mathrm{MeOH}$ (95:5) afforded compounds $\mathbf{1}(5.2 \mathrm{mg}), \mathbf{3}$ $(13.7 \mathrm{mg})$ and $\mathbf{4}(11.4 \mathrm{mg})$. Fraction II was subjected to silica gel column and eluted with $\mathrm{CHCl}_{3}: \mathrm{MeOH}$ (85:15) to afford compound 5 (18 $\mathrm{mg}$. Finally, fraction III was chromatographed on silica gel and eluted with $\mathrm{CHCl}_{3}: \mathrm{MeOH}$ (8:2), and further purified by silica gel column chromatography using $\mathrm{CHCl}_{3}: \mathrm{MeOH}$ $(8: 2)$ to yield compound $2(4.3 \mathrm{mg})$.

\section{Biological study Cytotoxicity assay}

The cytotoxicity was evaluated by the $\left[{ }^{3} \mathrm{H}\right]$ thymidine assay ${ }^{14}$ against mouse lymphoma (L5178Y) and rat brain cancer (PC33) cell lines. All cells were mycoplasma-free and cultures were propagated under standardised conditions ${ }^{15}$. 


\section{Antimicrobial assay}

The antibacterial and antifungal activities were evaluated using the agar plate diffusion assay ${ }^{16}$. Susceptibility discs $(5.5 \mathrm{~mm})$ were impregnated with solution of each of the alcoholic extract, compounds $\mathbf{1}$ and 2 at concentrations of 5 and 10 $\mathrm{g} / \mathrm{ml}$. The discs were dried and placed on agar plates inoculated with the test bacterial strains: $B$. subtilis, $S$. aureus, E. coli and N. gonorrhoea, and the fungal strains: $C$. albicans and A. flavus. Each plate was inoculated with a single organism and the test was run in duplicates. The plates were incubated at $37^{\circ} \mathrm{C}$ and checked for inhibition zones after 24 hrs for bacteria and after $48 \mathrm{hrs}$ for fungi. Benzyl-penicillin was used as a positive reference standard.

\section{RESULTS AND DISCUSSION}

Compound 1. Was isolated from choloroform/methanol (95:5) fraction, recrystallized from acetone as white needle crystals with melting point $151-153^{\circ} \mathrm{C}$. The EIMS showed molecular ion peak at $\mathrm{m} / \mathrm{z} 197$ $[\mathrm{M}+\mathrm{H}]^{+}$calculated for $\mathrm{C}_{11} \mathrm{H}_{16} \mathrm{O}_{3}$ with significant fragment ions at $\mathrm{m} / \mathrm{z} 181$ $\left[\mathrm{M}-\mathrm{CH}_{3}\right]^{+}, 178\left[\mathrm{M}-\mathrm{H}_{2} \mathrm{O}\right]^{+}, 163$ [M$\left.\mathrm{H}_{2} \mathrm{O}-\mathrm{CH}_{3}\right]^{+}$. The IR spectrum $(\mathrm{KBr})$ showed absorption bands at 3450 , 1735,1630 , and $850 \mathrm{~cm}^{-1}$ characteristic for the presence of hydroxyl group, $\quad \gamma$-lactone, $\quad \alpha, \beta$-unsaturated ketone, and tri-substituted double bond, respectively ${ }^{4}$. They were confirmed by the observed signals in ${ }^{1} \mathrm{H}$ - and ${ }^{13} \mathrm{C}$-NMR spectra at $\delta_{\mathrm{H}} 5.69 /$
$\delta_{\mathrm{C}} 113.2$ and 182.1 characteristic for the tri-substituted double bond $(\mathrm{H}-3$ /C-3), 4.31/66.9 (hydroxymethine) and at $\delta_{\mathrm{C}} 172.0$ and 87.0 for the lactone moiety. Furthermore, the ${ }^{1} \mathrm{H}-$ NMR spectrum (Table 1) showed the presence three methyl singlet signals: two of them were geminal methyl at $\delta_{\mathrm{H}} 1.27(\mathrm{Me}-10)$ and $1.47(\mathrm{Me}-11)$ and one at $\delta_{\mathrm{H}} 1.78(\mathrm{Me}-12)$ which was bound to a quaternary carbon. These findings were supported by the observed HMBC correlations of the olefenic proton at $\delta_{\mathrm{H}} 5.69(\mathrm{H}-3)$ and the carbons at $\delta_{\mathrm{C}} 182.1(\mathrm{C}-4), 172.0$ (C-2) and 87.0 (C-9). The HMBC cross peaks between Me-10 $\left(\delta_{\mathrm{H}} 1.27\right)$ with C-5, C-6 and C-4, Me-11 $\left(\delta_{\mathrm{H}}\right.$ 1.47) with C-5, C-6 and C-4, H-7 $\left(\delta_{\mathrm{H}}\right.$ 4.31) with $\mathrm{C}-6$ and $\mathrm{C}-8$, in addition to the cross peaks between Me-12 $\left(\delta_{\mathrm{H}}\right.$ 1.78) with C-9, C-8 and C-4. Compound 1 therefore corresponded to loliolide which was previously isolated from Alchornea glandulosa (Euphorbiaceae) $^{17}$, in addition to several plants including Eirmocephala megaphylla (Astraceae $)^{18}$, Digitalis lanata (Scrophulariaceae $)^{19}$ and Arnica Montana (Astraceae ${ }^{20}$. Loliolide was considered as a biosynthetic degradative product of terpenoids ${ }^{21}$. It is the first time of isolation for loliolide from genus Sonchus.

Compound 2. Was isolated as an oily residue from chlororform/ methanol (8:2) fraction. The EIMS showed a molecular ion peak at $\mathrm{m} / \mathrm{z}$ $443[\mathrm{M}+\mathrm{H}]^{+}$calculated for $\mathrm{C}_{21} \mathrm{H}_{31} \mathrm{O}_{10}$ with significant fragment ions at $\mathrm{m} / \mathrm{z}$ $427\left[\mathrm{M}-\mathrm{CH}_{3}\right]^{+}, 424\left[\mathrm{M}-\mathrm{H}_{2} \mathrm{O}\right]^{+}, 413$ 
$\left[\mathrm{M}-\mathrm{CHO}^{+}\right.$and $263[\mathrm{M}-\text { glucose }]^{+}$. The IR spectrum (KBr) showed similar diagnostic absorption bands to those of $\mathbf{1}$ at 3445 (hydroxyl group), $1770(\gamma$-lactone $)$ and $860 \mathrm{~cm}^{-1}$ due to tri-substituted double bond. The ${ }^{1} \mathrm{H}$ NMR spectrum (Table 1) showed signal for aldehydic proton at $\delta_{\mathrm{H}} 9.60$ (s), two olefenic protons at $\delta_{\mathrm{H}} 6.85(\mathrm{t}$, $J=8.5 \mathrm{~Hz})$ and $5.11(\mathrm{~d}, J=10.3 \mathrm{~Hz})$, in addition to a hydroxymethine at $\delta_{\mathrm{H}}$ $4.03(\mathrm{~m})$ and a secondary methyl at $\delta_{\mathrm{H}}$ 1.37 (d, $J=6.7 \mathrm{~Hz}$ ). Furthermore, the spectrum showed an anomeric proton of glucose at $\delta_{\mathrm{H}} 4.41$ with coupling constant $7.6 \mathrm{~Hz}$ indicated $\beta$ - configuration. The ${ }^{13} \mathrm{C}-\mathrm{NMR}$ (Table 2) showed the presence of 21 carbons, including six carbons of a glucopyarnosyl moiety. The DEPT and HMQC experiments confirmed the presence of the aldehydic carbon at $\delta_{\mathrm{C}} 199.8$, four olefinic carbons associated with two double bonds at $\delta_{\mathrm{C}} 129.4,137.0,144.6$ and 160.0, in addition to oxygenated methine at $\delta_{\mathrm{C}}$ 71.1 and an oxygenated methylene at $\delta_{\mathrm{C}}$ 67.5. The carbon resonances at $\delta_{\mathrm{C}}$ 41.0, 55.9, 76.2 and 180.0, in addition to the methyl at $\delta_{\mathrm{C}} 15.5$ indicated the presence of methyl- $\gamma$-lactone moiety ${ }^{8}$ as suggested by the IR spectrum. The

Table 1: ${ }^{1} \mathrm{H}-\mathrm{NMR}$ data of compounds $\mathbf{1}\left(\mathrm{CDCl}_{3}\right)$ and $2\left(\mathrm{DMSO}_{-}\right)$at $400 \mathrm{MHz}$.

$\left.\begin{array}{|c|c|c|}\hline \text { Position } & \mathbf{1} & \mathbf{2} \\ \hline 1 & - & 6.85(1 \mathrm{H}, \mathrm{t}, J=8.5 \mathrm{~Hz}) \\ \hline 2 & - & 2.51(2 \mathrm{H}, \mathrm{m}) \\ \hline 3 & 5.69(1 \mathrm{H}, \mathrm{s}) & 2.07(1 \mathrm{H}, \mathrm{m}) \\ 2.73(1 \mathrm{H}, \mathrm{m})\end{array}\right)$


Table 2: ${ }^{13} \mathrm{C}-\mathrm{NMR}$ data of compounds $1\left(\mathrm{CDCl}_{3}\right)$ and $\mathbf{2}$ $\left(\mathrm{DMSO}_{6} \mathrm{~d}_{6}\right.$ ) at $100 \mathrm{MHz}$.

\begin{tabular}{||c|c|c|}
\hline Position & $\mathbf{1}$ & $\mathbf{2}$ \\
\hline 1 & - & 160.0 \\
\hline 2 & 172.0 & 27.7 \\
\hline 3 & 113.2 & 33.3 \\
\hline 4 & 182.1 & 137.0 \\
\hline 5 & 35.8 & 129.4 \\
\hline 6 & 47.5 & 76.2 \\
\hline 7 & 66.9 & 55.9 \\
\hline 8 & 45.4 & 71.1 \\
\hline 9 & 87.0 & 32.7 \\
\hline 10 & 30.4 & 144.6 \\
\hline 11 & 26.5 & 41.0 \\
\hline 12 & 27.1 & 180.0 \\
\hline 13 & - & 15.7 \\
\hline 14 & - & 199.8 \\
\hline 15 & - & 67.5 \\
\hline glucose & - & 102.5 \\
\hline C-1 & & 73.4 \\
\hline C-2 & - & 76.8 \\
\hline C-3 & - & 69.7 \\
\hline C -4 & - & 76.0 \\
\hline C- 5 & - & 61.5 \\
\hline C -6 & - & \\
\hline & & \\
\hline
\end{tabular}

presence of the methyl- $\gamma$-lactone moiety was further confirmed by the HMBC cross peaks (Fig. 2), between
H-6 with C-7, H-7 with C-6 and C-11 and between $\mathrm{H}-11$ with $\mathrm{C}-12, \mathrm{C}-7$ and $\mathrm{C}-13$, moreover the cross peaks between Me-13 $\left(\delta_{\mathrm{H}} 1.37\right)$ with $\mathrm{C}-11$, confirmed the methyl- $\gamma$-lactone moiety. The sequence of the aliphatic and olefenic protons was made-up using the $\mathrm{H}-\mathrm{H}$ COSY experiment (Fig. 2), which afforded the series from $\mathrm{H}-1$ to $\mathrm{H}_{2}-3$ and from $\mathrm{H}-5$ to $\mathrm{H}_{2-}$ 9. The spin system from $\mathrm{H}-6$ to $\mathrm{H}_{3}-13$ through H-7 and H-11, afforded further evidence for the methyl- $\gamma$ lactone moiety. The HMBC cross peaks between $\mathrm{H}-1$ with $\mathrm{C}-10, \mathrm{H}_{2}-3$ with $\mathrm{C}-4, \mathrm{H}_{2}-9$ with $\mathrm{C}-10$ and $\mathrm{H}-5$ with $\mathrm{C}-6$ and $\mathrm{C}-4$, and the cross peaks between $\mathrm{H}_{2}-15$ with $\mathrm{C}-4$, indicated a costunolide nucleus ${ }^{22}$. The position of the aldehydic group at $\mathrm{C}-10$ was established by the HMBC correlation of $\mathrm{H}-14$ with $\mathrm{C}-10$. The cross peak of $\mathrm{H}_{2}-15$ with $\mathrm{C}-1^{\prime}$ indicated the attachment of the glucopyarnosyl moiety to C-15. From the abovementioned data 2 was identified as $\quad 15$-O- $\beta$-glucopyranosyl- $11 \beta, 13$ dihydrourospermal $A$ which was previously isolated from the roots of Sonchus asper ${ }^{6}$, but this is the first isolation from $S$. oleraceus.

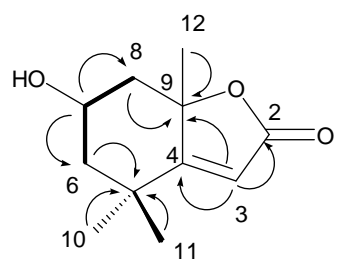

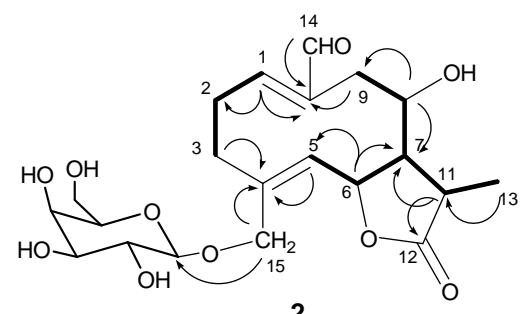

\section{- : H-H COSY}

$\frown:$ HMBC

Fig. 2: Important 2D correlations of compounds $\mathbf{1}$ and 2. 
Compounds 3-5 were identified as ursolic $\operatorname{acid}^{23}$, lupeol ${ }^{24}$ and $\beta$ sitoststerol-3- $O$ - $\beta$-glucopyranoside ${ }^{25}$, respectively on comparing their physical and spectral data with literatures. These compounds were isolated for the first time from $S$. oleraceus $\mathrm{L}$.

The in-vitro evaluation of the cytotoxic activity of compounds $\mathbf{1}$ and 2 using the thymidine assay, showed that $15-O-\beta$-glucopyranosyl-11 $\beta, 13$ dihydrourospermal A 2 was active against L5178Y and PC33 cell lines $\left(\mathrm{ED}_{50} \quad 6.2\right.$ and $5.2 \mu \mathrm{g} / \mathrm{ml}$, respectively), meanwhile loliolide $\mathbf{1}$ was active only against L5178Y $\left(\mathrm{ED}_{50} 4.7\right.$ $\mu \mathrm{g} / \mathrm{ml}$ ).

The antimicrobial activity of the alcoholic extract and compounds $\mathbf{1}$ and $\mathbf{2}$ (Table 3), revealed antibacterial activity against; $B$. Subtilis, E coli,
$S$. aureus and $N$. gonorrhoea. The alcoholic extract $(10 \mathrm{~g} / \mathrm{ml})$ showed inhibition zones of $10,9,9$ and 8 against the tested strains, respectively. Compound $2(10 \mathrm{~g} / \mathrm{ml})$ was the most active as it showed inhibition zones of $16,16,15$ and 15 , while compound 1 $(10 \mathrm{~g} / \mathrm{ml})$ was less active as the inhibition zones of 12, 13, 14 and 15 . None of the tested compounds or the alcoholic extract showed activity against the fungi $C$. albicans or $A$. flavus.

It is noteworthy to mention that this is the first cytotoxic and antimicrobial evaluation of loliolide $\mathbf{1}$ and $15-O-\beta$-glucopyranosyl-11 $\beta, 13-$ dihydrourospermal A $\mathbf{2}$, although loliolide was reported to have immunosuppressive activity against $\mathrm{T}$ and B-lymphocytes ${ }^{26}$.

Table 3: Inhibition zones of the alcoholic extract and compounds $\mathbf{1}$ and 2.

\begin{tabular}{|c|c|c|c|c|c|}
\hline \multicolumn{2}{|c|}{ Sample } & B. subtilis & E. coli & S. aureus & N. gonorrhoea \\
\hline \multirow[t]{2}{*}{ Alc. Ext. } & $5 \mu \mathrm{g}$ & 8 & 7 & 8 & 7 \\
\hline & $10 \mu \mathrm{g}$ & 10 & 9 & 9 & 8 \\
\hline \multirow[t]{2}{*}{1} & $5 \mu \mathrm{g}$ & 9.5 & 10 & 10.5 & 12 \\
\hline & $10 \mu \mathrm{g}$ & 12 & 13 & 14 & 15 \\
\hline \multirow[t]{2}{*}{2} & $5 \mu \mathrm{g}$ & 10.5 & 11 & 12 & 13.5 \\
\hline & $10 \mu \mathrm{g}$ & 16 & 16 & 15 & 15 \\
\hline
\end{tabular}




\section{REFERENCES}

1- R. M. Giner, A. Ubeda, M. J. Just, A. Serrano, S. Manez and J. L. Rios, Biochemical Systematics and Ecology, 21, 617 (1993).

2- A. S. Tomb, in "The Biology and Chemistry of Compositae", Academic Press, London, 1977, p. 1067.

3- Vivi Täckholm, "Student's Flora of Egypt", Cairo University press, Second Edition, 1974, p. 607.

4- J. B. Berrera, L. Fajardo and M. Gonzales, Tetrahedron Letters, 36, 3475 (1967).

5- Z. Mahmoud, S. El-Masry, M. Amer, J. Ziechen and M. Grenz, Phytochemistry,23, 1105 (1984).

6- A. M. Helal, N. Nakamura, H. El-Askary and M. Hattori, ibid., 53, 473 (2000).

7- S. Shimizu, T. Miyase, A. Ueno and K. Usmanghani, ibid, 28, 3399 (1989).

8- Z. Zhang, W. Xie, P. Li, Y. Shi and Z. Jia, Helvetica Chemica Acta, 89, 2927 (2006).

9- R. M. Mansour, N. A. Saleh and L. Boulos, Phytochemistry, 22, 489 (1983).

10- Z. Mahmoud, S. El-Masry, M. Amer, J. Zieschen and F. Bohlman, ibid., 22, 1290 (1983).

11- S. J. Quereshi, A. G. Awan, M. A. Khan and S. Bano, J. Biological Science, 2, 309 (2002).

12- M. D. Carnes and C. D. Carnes, "The Wild Flowering Plants of Bahrain. Illustrated Guide",
(IMMEL Publishing, 1989), p 225.

13- T. Miyase and S. Fukushima, Chemical Pharmacetical Bulletin, 35, 2869 (1987).

14- J. Carmichael, W. G. DeGraff, A. F. Gazdar, J. D. Minna and J. B. Mitchell, Cancer Research, 47, 943 (1987).

15- M. H. Kreuter, A. Robitzki,, S. Chang, R. Steffen, M. Michaelis, Z. Kljajic, M. Bachmann, H. C. Schröder and W. E. G. Muëller, Comparative Biochemical Physiology, 101C, 183 (1992).

16- E. Elkhayat, R. Edrada, R. Ebel, V. Wray, R. Van Soest, S. Wiryowidagdo, H. M. Mohammed, W. E. Muller and P. Proksch, J. Natural Products, 67, 1809 (2004).

17- L. S. Conegero, R. M. Ide, A. S. Nazari and M. H. Sarragiotto, Quim Nova, 26, 825 (2003).

18- S. Borkosky, D. A. Valdes, A. Bardon, J. G. Diaz and W. Herz, Phytochemistry, 42, 1637 (1996).

19- A. A. Khalifa, "Study of Sesqueterpene Lactones of Venidium fastuosum Stapf from Family Compositae (Astraceae) Cultivated in Egypt", Ph.D Thesis, Assiut University, Egypt (1986).

20- M. Holub, Z. Samek and J. Poplawski, Phytochemistry, 14, 1659 (1975).

21- T. K. Davon and A. I. Scott "Handbook of Naturally ocuuring Compounds", Vol. II, 
Academic Press, New York, London, 1972, p. 503.

22- M. Ogura, G. A. Cordell and N.

R. Farnsworth. Phytochemistry, 17, 957 (1978).

23- S. Said and S. Begum, Chemistry of Natural Compounds, 40, 138 (2004).

24- W. Seebacher, N. Simic, R. Weis, R. Saf and O. Kunert, Magnetic Resonance Chemistry, 41, 636 (2003).
25- S. Faizi, M. Ali, R. Saleem, Irfanullah and S. Bibi, ibid., 39, 399 (2001).

26- N. Okada, K. Shirata, M. Niwano, H. Koshino and $M$. Uramoto, Phytochemistry, 37, 281 (1994). 